\title{
IMPLEMENTASI MODEL PEMBELAJARAN MAKE A MATCH DALAM MENINGKATKAN HASIL BELAJAR SISWA DI KELAS IV SD INPRES KOBISONTA A1
}

\author{
Taha Basalama \\ Kepala Sekolah pada Sekolah Dasar Inpres Kobisonta A1
}

\section{ARTICLE INFO}

Article History:

Accepted 10 September 2017

Available online 20 Oktober 2017

Keywords:

Model Pembelajaran Make a

Match, Hasil Belajar Siswa.

\begin{abstract}
Implementasi model pembelajaran di sekolah merupakan salah satu langkah strategi yang dilakukan oleh guru dalam membangun pembelajaran yang berpihak kepada siswa. Untuk itu, maka guru dituntut dapat menguasai sejumlah model pembelajaran yang diharapkan dapat membantu guru mengembangkan pembelajaran di kelas, sehingga siswa dapat dengan mudah merekonstrauksi pembelajaran yang memungkinkan terjadinya peningkatan hasil belajar siswa. Penelitian ini menggunakan tipe penelitian tindakan kelas (PTK) yang difokuskan pada siswa kelas IV pada mata pelajaran IPS. Hasil penelitian ini menunjukan bahwa model pembelajaran Make A Match dapat meningkatkan hasil belajar siswa.
\end{abstract}

\section{PENDAHULUAN}

Pendidikan di Indonesia dewasa ini menunjukkan perkembangan yang cukup pesat sedangkan keberhasilan dalam dunia pendidikan tidak lepas dari proses pembelajaran. Dalam proses pembelajaran terjadi transfusi ilmu dari para pengajar kepada peserta didik yang hasilnya dapat dilihat pada hasil belajar siswa. Usahausaha ke arah peningkatan kualitas pendidikan masih diteruskan secara sistematis. Salah satu upaya peningkatan kualitas pendidikan yaitu dengan cara pembaharuan dalam bidang pendidikan melalui metode atau strategi pembelajaran. Dengan pembaharuan strategi pembelajaran diharapkan sumber informasi yang diterima siswa tidak hanya dari guru, tetapi juga memberikan motivasi dan minat pada siswa dalam 
mempelajari dan memahami ilmu yang ada. Hal ini akan menuntut guru dapat menyampaikan mata pelajaran dengan strategi yang tepat. Hasil belajar anak sebagai salah satu indikator mutu pendidikan dipengaruhi oleh hal-hal yang berasal dari dalam diri siswa dan dari luar siswa (Sumadi Suryabrata, 1983: 127).

Bloom, (1976: 95) menyatakan bahwa prestasi belajar dipengaruhi oleh kemampuan efektif, kognitif dan kualitas pengajaran. Salah satu upaya pembaharuan dalam bidang pendidikan adalah meningkatkan strategi dalam pembelajaran. Strategi pembelajaran relevan jika mampu menghantarkan siswa mencapai tujuan pendidikan yang diharapkan melalui pembelajaran. Dengan pembaharuan strategi diharapkan sumber informasi yang diterima siswa tidak hanya dari guru, tetapi juga memberikan minat dan motivasi pada siswa dalam mempelajari dan menelaah ilmu yang ada. Hal ini akan menuntut guru untuk dapat menyampaikan mata pelajaran dengan tepat Ilmu Pengetahuan Sosial adalah terjemahan dari apa yang di dunia pendidikan dasar dan lanjutan Amerika Serikat dinamakan sosial studies, boleh diartikan penelaahan masyarakat (H. Daldjoeni, 1981: 6). Dalam buku pedoman khusus badang studi IPS menurut kurikulum 1975, ruang lingkup dan tata urut bahan pengajaran IPS adalah perpaduan antara IPS dan PMP, Ilmu Pengetahuan Sosial didefinisikan sebagai ilmu pengetahuan tentang manusia di dalam kelompok yang disebut masyarakat dan menggunakan ilmu politik, ekonomi, sejarah, geografi, sosial, antropologi, dan sebagainya.

Pendidikan Ilmu Pengetahuan Sosial diberikan dengan maksud untuk meningkatkan kualitas atau mutu pengajaran dalam proses belajar mengajar. Guna meningkatkan tujuan tersebut diperlukan tingkat dan jenjang pendidikan SD, SLTP, dan SLTA. Pada jenjang pendidikan untuk SD menitikberatkan pada pendidikan dasar termasuk mata pelajaran IPS, diukur sejauh mana penguasaan anak terhadap materi koperasi. Banyak orang yang memandang mata pelajaran, Ilmu Pengetahuan Sosial sebagai bidang pelajaran yang menjemukan. Meskipun demikian, semua orang harus mempelajarinya karena merupakan sarana untuk memecahkan masalah kehidupan sehari-hari. Seperti halnya berhitung, bahasa. membaca dan menulis. Kejemuan belajar Ilmu Pengetahuan Sosial harus diatasi sedini mungkin. Maka kewajiban bagi guru untuk menanamkan cara senang terhadap materi Ilmu Pengetahuan Sosial. Hasil belajar Ilmu Pengetahuan Sosial merupakan salah satu tujuan pembelajaran yang dapat memacu perkembangan Ilmu Pengetahuan dan Teknologi. Salah satu penyebab rendahnya hasil belajar Ilmu Pengetahuan Sosial adalah model pembelajaran yang dipilih guru kurang tepat.

Berdasarkan hasil tes akhir semester dan laporan pendidikan yang diperoleh dari guru mata pelajaran IPS di SD Inpres Kobisonta A1, khususnya dikelas IV dijumpai guru hanyalah menggunakan metode ceramah. Oleh karena itu, maka untuk 
meningkatkan hasil belajar siswa dalam Ilmu Pengetahuan Sosial perlu dilakukan model baru dalam pembelajaran diantaranya melalui model pembelajaran Mencari pasangan (make a match). Model pembelajaran mencari pasangan (make a match) paling cocok diterapkan pada mata pelajaran ilmu-ilmu sosial, sastra, beberapa bagian sains dan bidang studi lain yang tujuan pelajarannya lebih menekankan pada konsep daripada ketrampilan. Model pembelajaran mencari pasangan merupakan model pembelajaran, dimana teknik yang terkandung didalamnya bisa memberikan kesempatan kepada siswa untuk saling membagikan ide-ide dan mempertimbangkan jawaban yang paling tepat, selain itu teknik yang terdapat didalamnya juga mendorong siswa untuk meningkatkan semangat kerja sama mereka di sekolah pada saat guru memberikan pembelajaran terdapat gejala misalnya : prestasi rendah, semangat belajar kurang. Melalui model pembelajaran mencari pasangan diharapkan dapat meningkatkan prestasi belajar dan semangat belajar siswa.

\section{KAJIAN PUSTAKA}

\section{Pengertian Belajar}

Belajar adalah suatu proses yang ditandai dengan adanya perubahan pada diri seseorang. Perubahan sebagai hasil dari proses belajar dapat ditunjukkan dalam bernagai bentuk seperti perubahan pengetahuan, sikap, dan tingkah laku, ketrampilan, kebiasaan, serta perubahan aspek-aspek lain yang ada pada individu yang belajar. R. Gape dalam Slameto (2003: 13; Nana Sudjana, 1989: 5) memberikan 2 definisi mengenai belajar : belajar adalah suatu proses untuk memeperoleh motivasi dalam pengetahuan, ketrampilan, kebiasaan, dan tingkah laku. Hal yang sama juga dikemukakan oleh Slameto (2003: 2) bahwa belajar adalah penguasaan pengetahuan atau ketrampilan yang diperoleh melalui interaksi. Belajar juga merupakan usaha yang dilakukan seseorang untuk memperoleh suatu perubahan tingkah laku yang ada secara keseluruhan sebagai hasil pengalamannya sendiri dalam interaksi dengan lingkungan. Menurut Cronbach di dalam bukunya Educational Psychology (Suryabrata, 2004: 23 ) menyatakan bahwa "Learrung is shown by a change in behavior as a result of experience". Artinya belajar adalah sesuatu yang ditunjukkan oleh perubahan tingkah laku yang disebabkan oleh pengalaman.

Pernyataan senada juga diutarakan oleh Morgan, di dalam buku Introduction of Psychology (Purwanto, 2007: 84) menyatakan bahwa belajar adalah perubahan yang relatif menetap dalam tingkah laku yang terjadi sebagai suatu hasil dari latihan atau pengalaman. Berdasarkan beberapa pendapat di atas mengenai pengertian belajar dapat disimpulkan bahwa belajar merupakan perubahan perilaku yang terjadi karena didahului oleh proses pengalaman dan perubahan tersebut bersifat relative permanent. Sedangkan menurut Winkel (1996: 53) belajar adalah suatu aktivitas mental/psikis 
yang berlangsung dalam interaksi aktif dengan lingkungan, yang menghasilkan perubahan-perubahan dalam pengetahuan, pemahaman, keterampilan sikap. Perubahan itu bersifat secararelatif konstan dan berbekas. Sedangkan menurut Walker (dalam riyanto, 2002) belajar adalah suatu perubahan dalam pelaksanaan tugas yang terjadi sebagai hasil dari pengalaman dan tidak ada sangkut pautnya dengan kematangan rohaniah, kelelahan, motivasi, perubahan dalam situasi stimulus atau faktor-faktor lainnya yang tidak berhubungan langsung dengan kegiatan belajar.

\section{Model Pembelajaran Make a Match}

Pembelajaran make a match merupakan model pembelajaran aktif, efektif, dan menyenangkan (PAKEM), merupakan kelompok dari pembelajaran kooperatif (Coopreatif Learning) yang mengutamakan kerja sama dan kecepatan di antara siswa untuk mencapai tujuan pembelajaran. Model pernbelajaran ini memiliki ciri-ciri yaitu untuk menuntaskan materi belajarnya, siswa belajar dalam kelompok atau bersama siswa lain. Model pembelajaran make a match (mencari pasangan) merupakan strategi pembelajaran yang dikembangkan oleh Lerna Curran (Depdiknas, 2005) mempunyai langkah-langkah sebagai berikut :

a) Guru menyiapkan beberapa kartu yang berisi beberapa konsep atau topik yang cocok untuk sesi review. Sebaiknya satu bagian kartu soal dan bagian lainnya kartu jawaban.

b) Setiap siswa mendapat satu buah kartu.

c) Tiap siswa memikirkan jawaban/soal dari kartu yang dipegang.

d) Setiap siswa mencari pasangan yang mempunyai kartu yang cocok dengan kartunya (soal/jawaban).

e) Setiap siswa yang dapat mencocokkan hasilnya sebelum batas waktu diberi point.

f) Setelah satu babak kartu dikocok kagi agar tiap siswa mendapat kartu yang berbeda dari sebelumnya demikian seterusnya.

g) Mengambil kesimpulan/penutup

Model pembelajaran make a match merupakan strategi yang cukup menyenangkan yang digunakan untuk mengulang materi yang telah diberikan sebelumnya. Namun demikian materi barupun tetap bisa diajarkan menggunakan model pembelajaran make a match, dengan catatan peserta didik diberi tugas mempelajari topik yang akan diajarkan terlebih dahulu, sehingga ketika masuk kelas mereka sudah memiliki bekal pengetahuan (Hisyam Zain, 2008: 32).

Proses pembelajaran merupakan interaksi antara siswa dengan guru dan sumber belajar pada suatu lingkungan belajar. Dalam proses pembelajaran baik guru maupun siswa dituntut aktif dalam proses pembelajaran. Berdasarkan hal tersebut di atas dibutuhkan sebuah model pembelajaran yaitu model pembelajaran 'Make A Match' 
yang dapat memberikan kesempatan kepada siswa untuk bekerja sama dengan orang lain. Pada tahap awal guru mengadakan pembelajaran dengan metode ceramah atau bercerita. Pada materi koperasi menggunakan metode pembelajaran ceramah atau bercerita hasil belajar siswa minim. Hal ini ditunjukkan dengan perolehan nilai ulangan dibawah Kriteria ketuntasan Minimal (KKM). Berdasarkan pengalaman di atas penulis ingin mencoba melaksanakan pembelajaran menggunakan model pembelajaran make a match (mencari pasangan). Pada pembelajaran make a match ini anak belajar sambil bermain mencari pasangan kartu yang dipegangnya, sehingga anak merasa senang. Dengan demikian pembelajaran menggunakan model 'make amatch' ini , pada sesi review diharapkan dapat meningkatkan hasil belajar siswa terutama pada materi koperasi. Hipotesis Penelitian berdasarkan rumusan masalah, kajian teori, dan kerangka perpikir di atas, maka peneliti mengambil hipotesis bahwa menggunakan model pembelajaran 'make a match' (mencari pasangan) dengan cara bermain kartu dapat meningkatkan pemahaman dan hasil belajar siswa terhadap materi koperasi di Kelas IV SD Inpres Kobisonta A1.

Hisyam Zain (2008) mengemukakan kelebihan dan kelemahan Model Pembelajaran Make A Match. Adapun kelebihan bagi siswa diantaranya sebagai berikut

a. Mampu menciptakan suasana belajar aktif dan menyenangkan

b. Materi pembelajaran yang disampaikan lebih menarik perhatian siswa

c. Mampu meningkatkan hasil belajar siswa mencapai taraf ketuntasan belajar secara klasikal $87,50 \%$

d. Suasana kegembiraan dalam proses pembelajaran (Let them move)

e. Kerja sama antar sesama siswa terwujud dengan dinamis

f. Munculnya dinamika gotong royong yang merata diseluruh siswa.

Disamping kelebihan yang dirasakan oleh siswa, pembelajaran kooperatif model make a match berdasarkan temuan dilapangan mempunyai sedikit kelemahan.

a. Diperlukan bimbingan dari guru untuk melakukan kegiatan.

b. Waktu yang tersedia perlu dibatasi jangan sampai siswa terlalu banyak bermainmain dalam proses pembelajaran.

c. Guru perlu persiapan bahan dan alat yang memadai.

d. Pada kelas yang gemuk (30 siswa/kelas) jika kurang bijaksana maka yang muncul adalah suasana seperti pasar dengan keramaian yang tak terkendali. Tentu saja kondisi ini akan mengganggu ketenangan belajar kelas dikiri kanannya. Tetapi hal ini bisa diantisipasi dengan menyepakati beberapa komitmen ketertiban dengan siswa sebelum "pertunjukan" dimulai. Pada dasarnya mengendalikan kelas itu tergantung bagaimana kita memotivasinya pada langkah pembukaan. 


\section{Hasil Belajar}

Hasil belajar adalah penguasaan pengetahuan atau ketrampilan yang dikembangkan oleh mata pelajaran umumnya ditunjukkan dengan nilai tes atau nilai yang diberikan oleh guru (Depdiknas, 2005: 895). Menurut Anni (2006: 5), Hasil belajar merupakan perubahan tingkah laku yang diperoleh pelajar setelah mengalami aktivitas belajar. Sedangkan pengertian hasil belajar menurut Sukmadinata (2007:

102-103) adalah realisasi atau pemekaran dari kecakapan-kecakapan potensial atau kapasitas yang dimiliki seseorang. Penguasaan hasil belajar seseorang dapat dilihat dari perilakunya, baik perilaku dalam bentuk penguasaan pengetahuan, ketrampilan berpikir maupun ketrampilan motorik. Menurut Gagne (dalam Dimyanti 1994 : 11) proses kognitif menghasilkan suatu hasil belajar, hasil belajar tersebut terdiri dari : keterampilan intelektual, keterampilan motorik, sikap dan strategi kognitif. Hasil belajar merupakan kemampuan vang dapat diukur berupa penguasaan pengetahuan, sikap dan ketrampilan sebagai hasil dari kegiatan pembelajaran.

\section{METODOLOGI}

Tipepenelitian yang digunakan dalam penelitian ini adalah penelitian tindakan kelas. Menurut Arikunto (2006: 3) PTK adalah suatu pengamatan terhadap aktifitas belajar yang berupa sebuah tindakan yang sengaja dilakukan dikelas. Tindakan dimaksud dilakukan oleh guru untuk meningkatkan aktivitas mengajar dan hasil belajar. Langkah-langkah yang digunakan dalam penelitian ini yakni di gambarkan oleh Kurt Lewin. Muhamad (2005: 10) mengatakan bahwa model Kurt Lewin menjadi acuan dari berbagai model penelitian tindakan, karena Kurt Lewin yang pertama kali memperkenalkan penelitian tindakan atau action research. Komponen dalam penelitian tindakan kelas ini, yakni : 1). Perencanaan (planning), 2). Tindakan (acting), 3). Pengamatan (observing), dan 4). Refleksi (reflection).

\section{HASIL PENELITIAN}

\section{Hasil Penelitian Siklus I}

\section{a. Perencanaan Tindakan}

Pembelajaran IPS dengan materi peniggalan sejarah pada siklus I merupakan pemberlakuan tindakan awal penelitian dengan model make a match. Tindakan siklus I dilaksanakan sebagai upaya untuk memperbaiki dan memecahkan masalah yang dihadapi siswa kelas IV SD Inpres Kobisonta A1. Dalam perencanaan ini peneliti menyusun perangkat pembelajaran berupa Rencana Pelaksanaan Pembelajaran (RPP) siklus 1 (lampiran 3), menyusun Lembar Kerja Siswa (LKS) dan format pengamatan untuk siswa.Selain itu juga ditetapkan 
kriteria penilaian yaitu pelaksanaan tindakan dikatakan berhasil jika $>65 \%$ siswa mencapai kriteria ketuntasan.

\section{b. Pelaksanaan Tindakan}

Pelaksanaan tindakan dalam pembelajaran model make a match dengan rencana pembelajaran yang telah disusun pada tahap perencanaan. Siklus I terdiri dari dua pertemuan dan materi yang diajarkan adalah peniggalan sejarah. Diakhiri pertemuan siklus pertama dilakukan tes akhir siklus.

\section{Pertemuan Pertama}

Pertemuan pertama pada tanggal 1 September 2016, guru bersama observer masuk kedalam kelas dan guru memberikan salam kepada siswa. Selanjutnya guru memberikan petuntuk mengenai pelajaran yang diajarkan pada hari ini dan indikator keberhasilan yang akan dicapai. Guru sebagai peneliti membuka pelajaran dengan menjelaskan materi yang akan diajarkan mengenai peninggalan sejarah. Pada tahap ini siswa diharapkan mampu menjaskan peninggalan sejarah dan siswa dapat mendemonstrasikan dengan model pembelajaran make a match. Setelah siswa memperhatikan, guru memberikan penjelasan singkat mengenai peninggalan sejarah dan mendemonstrasikan model make a match didepan kelas. Siswa dibagi dalam kelompok untuk mencari pasangan sesuai dengan kartu yang cocok dengan kartunya (soal jawaban), siswa juga mengerjakan Lembar Kerja Siswa (LKS) yang telah disediakan dengan pengawasan guru dan observer .Pada saat kegiatan pembelajaran dilaksanakan, guru menyampaikan tujuan pembelajaran untuk dipahami oleh siswa.Guru juga memperingatan siswa agar dalam mengerjakan LKS harus secara individu. Karena waktu pembelajaran akan selesai guru menutup pelajaran hari ini dan akan dilanjutkan pada hari pertemuan berikutnya.

\section{Pertemuan Kedua}

Pertemuan berlangsung pada tanggal 8 September 2016. Mengawali pertemuan ini, guru menanyakan kembali materi yang diajarkan pada pertemuan pertama dan menanyakan kepada siswa apakah ada yang menemui kesulitan dalam mengerjakan LKS pada pertemuan sebelumnya, sebagian siswa menjawab ada, kemudian guru mempersilahkan untuk mengemukakan masalahnya. Mereka menjawab belum menyelesaikan LKSnya sehingga guru membagi siswa kedalam kelompok untuk mencari pasangan serta membagikan kartu soal dan jawaban sesuai dengan soal LKS yang belum dapat diselesaikan oleh siswa, setelah satu babak guru mengkocok lagi agar siswa mendapatkan kartu yang berbeda. Guru 
memberikan motivasi dan arahan kepada siswa agar semua aktif dalam mencari pasangan sesuai dengan kartunya. Setelah selesai mencari pasangan sesuai dengan kartunya, guru kemudian menanyakan kembali kepada siswa kartu soal dan jawaban serta siswa menjawab.Setelah siswa memberikan tanggapan terhadap hasil dari mencari pasaangan sesuai dengan kartunya maka guru memberikan pujian kepada siswa yang memberikan tanggapan dan guru menyimpulkan keseluruhan materi yang diajarkan tentang peninggalan sejarah dengan model mencari pasangan. Pada akhir pertemuan guru memberikan tes siklus I.

\section{c. Pengamatan/Observasi}

Kondisi yang diamati selama tindakan ini adalah sebagai berikut : kondisi kelas masih jadi masalah, beberapa faktor yang membuat hal ini terjadi adalah kurangnya perhatian siswa terhadap apa yang disampaikan guru akibat kegaduhan dalam kelas, sikap siswa yang kurang relevan dalam menerima pelajaran.Adapun dari keseluruhan siklus I ini, guru masih kurang memberikan motivasi kepada semua siswa untuk bekerja dengan baik. Peningkatan hasil belajar telah terjadi pada siklus I ini, dimana nilai-nilai siswa telah mengalami peningkatan dari tes awal yang dilakukan.Meskipun secara keseluruhan peningkatan ini belum mencapai kriteria penilaian yang ditetapkan sebelumnya. Hasil tes siklus I dapat dilihat pada tabel 1 berikut :

Tabel 1 Hasil Tes Akhir Siklus I

\begin{tabular}{|c|c|c|c|c|}
\hline \multirow{2}{*}{ No } & \multirow{2}{*}{ Inisial Siswa } & \multirow{2}{*}{ Nilai Siswa } & \multicolumn{2}{|c|}{ Kategori } \\
\hline & & & Tuntas & Tidak Tuntas \\
\hline 1 & $\mathrm{ABL}$ & 50 & & $\sqrt{ }$ \\
\hline 2 & $\mathrm{DE}$ & 40 & & $\sqrt{ }$ \\
\hline 3 & $\mathrm{~S}$ & 80 & $\sqrt{ }$ & \\
\hline 4 & $\mathrm{DE}$ & 80 & $\sqrt{ }$ & \\
\hline 5 & FK & 80 & $\sqrt{ }$ & \\
\hline 6 & LB & 30 & & $\sqrt{ }$ \\
\hline 7 & NP & 80 & $\sqrt{ }$ & \\
\hline 8 & PD & 20 & & $\sqrt{ }$ \\
\hline 9 & SF & 60 & & $\sqrt{ }$ \\
\hline 10 & RA & 80 & $\sqrt{ }$ & \\
\hline 11 & SJ & 50 & & $\sqrt{ }$ \\
\hline 12 & LGM & 80 & $\sqrt{ }$ & \\
\hline 13 & TR & 80 & $\sqrt{ }$ & \\
\hline 14 & ED & 40 & & $\sqrt{ }$ \\
\hline 15 & UL & 60 & & $\sqrt{ }$ \\
\hline 16 & TPL & 80 & $\sqrt{ }$ & \\
\hline
\end{tabular}




\begin{tabular}{|c|c|c|c|c|}
\hline 17 & $\mathrm{HK}$ & 60 & & $\sqrt{ }$ \\
\hline 18 & $\mathrm{~L}$ & 80 & $\sqrt{ }$ & \\
\hline 19 & YT & 40 & & $\sqrt{ }$ \\
\hline 20 & OB & 20 & & $\sqrt{ }$ \\
\hline 21 & $\mathrm{DE}$ & 30 & & $\sqrt{ }$ \\
\hline 22 & GT & 80 & $\sqrt{ }$ & \\
\hline 23 & PI & 30 & & $\sqrt{ }$ \\
\hline 24 & SAD & 20 & & $\sqrt{ }$ \\
\hline 25 & MAK & 80 & $\sqrt{ }$ & \\
\hline 26 & MEL & 40 & & $\sqrt{ }$ \\
\hline 27 & IGR & 80 & $\sqrt{ }$ & \\
\hline 28 & KD & 80 & $\sqrt{ }$ & \\
\hline 29 & LEB & 50 & & $\sqrt{ }$ \\
\hline 30 & NKI & 80 & $\sqrt{ }$ & \\
\hline & lah & 30 & 14 & 16 \\
\hline & ta-Rata & 58,67 & & \\
\hline \multicolumn{3}{|c|}{$\begin{array}{l}\text { Persentase } \\
\end{array}$} & $46,67 \%$ & $53,33 \%$ \\
\hline
\end{tabular}

Berdasarkan tabel diatas, terlihat bahwa siswa yang telah mencapai Kriteria Ketuntasan Minimal (KKM) adalah 14 orang atau sekitar $46.67 \%$ dan siswa yang belum mencapai Kriteria Ketuntasan Minimal (KKM) adalah 16 orang atau sekitar $53.33 \%$. Hasil tes pembelajaran IPS pada siklus I baru mencapai nilai $46.67 \%$ yang mencapai KKM.Nilai tes siklus I belum dapat dikatakanmemuaskan karena hasilnya masih minim dan belum mencapai target pencapaian penilaian yang ditetapkan yaitu $>65 \%$.

\section{d. Refleksi}

Berdasarkan hasil tindakan proses pembelajaran IPS dengan materi peninggalan sejarah dengan menggunakan model make a match serta hasil evaluasi oleh guru dan observer mengadakan refleksi untuk menetapkan temuan-temuan yang berkaitan dengan upaya peningkatan kualitas pembelajaran IPS. Karena dilihat dari hasil evaluasi hasil tes siklus I rata-rata kelas $<65 \%$ maka kegiatan pembelajaran IPS dengan materi peniggalan sejarah dilanjutkan pada siklus II.

\section{Hasil Penelitian Siklus II}

Pada siklus II ini di lakukan karena perbaikan-perbaikan terhadap materi yang telah di ajarkan pada siklus I. Dengan demikian perlu adanya perbaikan agar siswa mampu mendapatkan hasil yang lebih baik..Penelitian siklus II ini dilakukan dengan rencana dan persiapan yang lebih matang dibandingkan dengan siklus I. Dengan adanya perbaikan-perbaikan dalam pembelajaran siklus II ini, maka hasil penelitian yang berupa nilai tes mengalami peningkatan.. Tindakan siklus II dilaksanakan 
sebagai upaya untuk memperbaiki dan memecahkan masalah pembelajaran IPS khususnya peninggalan sejarah yang ditemui atau didengar oleh siswa kelas IV SD Inpres Kobisonta A1. Pelaksanaan pembelajaran dengan model make a match pada siklus II terdiri dari perencanaan, tindakan, observasi, dan refleksi dijelaskan sebagai berikut :

\section{a. Perencanaan Tindakan}

Dengan memperhatikan kelemahan dan kekurangan pada pelaksanaan siklus I dibuat perencanaan sebelum pelaksanaan tindakan siklus II, adapun hal-hal yang harus dibuat adalah :

a. Membuat RPP siklus IIdan memperbaiki langkah pembelajaran pertemuan ketiga dan keempat.

b. Siklus II masih menggunakan format observasi yang disusun pada tahap perencanaan sebelumnya.

c. Perlu adanya perhatian yang serius dari guru kepada siswa dalam proses pembelajaran.

d. Menetapkan kriteria penilaian dimana siklus ini dikatakan berhasil jika lebih dari $65 \%$ siswa mencapai kriteria $\mathrm{KKM}>65$.

\section{b. Pelaksanaan Tindakan}

Prosedur tindakan siklus II telah diterapkan dengan baik, yaitu mencakup semua unsur sesuai rencana pembelajaran yang telah disusun pada tahap perencanaan.Pelaksanaan pembelajaran pada siklus II berlangsung dalam2 pertemuan.Materi bahasan yang dibahas dalam pertemuan 1 dan 2 adalah peninggalan sejarah.Pada akhir pertemuan kedua dilakukan tes akhir siklus.

\section{Pertemuan Pertama}

Pertemuan ketiga dilakukan pada tanggal 15 September 2016 pada siklus ini guru masuk kedalam kelas bersama dengan observer, kemudian siswa member salam. Guru menenangkan siswa untuk siap dalam pembelajaran serta mengambil absen kelas. Sebelum pelajaran dimulai guru menyampaikan peningkatan hasil tes pada siklus I. Selanjutnya guru memulai pembelajaran dengan meminta semua siswa harus serius dan memperhatikan dengan baik kedepan kelas. Guru meminta observer untuk mengambil posisi dalam mengamati aktivitas siswa berdasarkan lembar observasi yang telah disiapkan sebelumnya. Observer melihat aktifitas siswa selama proses pembelajaran berlangsung dan mengisi format observasi yang telah disediakan. Guru menjelaskan tujuan pembelajaran dan materi yang akan diajarkan kepada siswa yaitu peninggalan sejarah. Guru menjelaskan secara singkat tentang peninggalan sejarah dan guru membagi siswa kedalam 
kelompok untuk mencari pasangan sesuai dengan kartu jawaban dan soal. Guru memberi motivasi kepada siswa, siapa yang dapat mencocokkan kartunya diberi poin sehingga semua siswa berpartisipasi dalam mencari kartu yang cocok dengan kartunya. Guru meminta siswa untuk mengerjakan LKS. Ketika siswa selesai mengerjakan LKS. Guru menutup pelajaran pada pertemuan pertama dengan memberikan PR kepada siswa.

\section{Pertemuan Kedua}

Pertemuan keempat dilaksanakan pada tanggal 22 September 2016. Sebelum guru memulai pelajaran, guru menyiapkan kelas dan mengambil absen siswa. Guru meminta ketua kelas untuk mengumpulkan PR didepan. Guru membahas PR yang dianggap sulit oleh siswa. Selanjutnya guru membagikan siswa kedalam kelompok untuk mencarinya pasangan sesuai dengan kartunya dan sesuai dengan soal PR. Setelah siswa yang dapat menemukan kartu yang sesuai dengan kartunya maka guru memberikan pujian kepadanya dan memotivasi siswa yang belum dapat menemukan kartu yang sesuai dengan kartunya. Akhir pertemuan ini guru melaksanakan tes yang berhubungan dengan materi yang telah diajarkan.

\section{c. Observasi}

Aktifitas dari masing-masing siswa dalam siklus ini dapat dirincikan sebagai berikut :

a) Peneliti mengamati pembelajaran IPS dengan materi peninggalan sejarah dengan rencana pembelajaran.

b) Perhatian seluruh siswa ketika menerima penjelasan guru sangat baik, dimana dalam pertemuan kedua mendapat respons positif, semua siswa aktif dalam memperhatiakan proses pembelajaran.

c) Adapun aktivitasi guru dalam siklus ini juga sudah membaik, dimana guru tegas dan cukup memperhatikan keadaan siswa, teguran-teguran yang diberikan membuat perhatian siswa bisa kembali dalam proses pembelajaran, akan tetapi usaha guru dalam memberikan bimbingan kepada seluruh siswa masih terasa kurang dengan demikian proses bimbingan ini belum berlangsung secara maksimal. Adapun hasil tes akhir pada siklus kedua ini mengalami peningkatan dari siklus sebelumnya. Nilai tes akhir siklus II ini dapat dilihat pada tabel 2 sebagai berikut : 
Tabel 2. Hasil Tes Akhir Siklus II

\begin{tabular}{|c|c|c|c|c|}
\hline \multirow{2}{*}{ No } & \multirow{2}{*}{ Inisial Siswa } & \multirow{2}{*}{ Nilai Siswa } & \multicolumn{2}{|c|}{ Kategori } \\
\hline & & & Tuntas & Tidak Tuntas \\
\hline 1 & $\mathrm{ABL}$ & 80 & $\sqrt{ }$ & \\
\hline 2 & $\mathrm{DE}$ & 80 & $\sqrt{ }$ & \\
\hline 3 & $\mathrm{~S}$ & 90 & $\sqrt{ }$ & \\
\hline 4 & $\mathrm{DE}$ & 80 & $\sqrt{ }$ & \\
\hline 5 & FK & 90 & $\sqrt{ }$ & \\
\hline 6 & LB & 90 & $\sqrt{ }$ & \\
\hline 7 & NP & 80 & $\sqrt{ }$ & \\
\hline 8 & PD & 50 & & $\sqrt{ }$ \\
\hline 9 & SF & 80 & $\sqrt{ }$ & \\
\hline 10 & RA & 100 & $\sqrt{ }$ & \\
\hline 11 & SJ & 80 & $\sqrt{ }$ & \\
\hline 12 & LGM & 40 & & $\sqrt{ }$ \\
\hline 13 & $\mathrm{TR}$ & 90 & $\sqrt{ }$ & \\
\hline 14 & ED & 80 & $\sqrt{ }$ & \\
\hline 15 & UL & 100 & $\sqrt{ }$ & \\
\hline 16 & TPL & 70 & $\sqrt{ }$ & \\
\hline 17 & $\mathrm{HK}$ & 90 & $\sqrt{ }$ & \\
\hline 18 & $\mathrm{~L}$ & 100 & $\sqrt{ }$ & \\
\hline 19 & YT & 80 & $\sqrt{ }$ & \\
\hline 20 & OB & 100 & $\sqrt{ }$ & \\
\hline 21 & $\mathrm{DE}$ & 40 & & $\sqrt{ }$ \\
\hline 22 & GT & 80 & $\sqrt{ }$ & \\
\hline 23 & PI & 90 & $\sqrt{ }$ & \\
\hline 24 & SAD & 60 & & $\sqrt{ }$ \\
\hline 25 & MAK & 100 & $\sqrt{ }$ & \\
\hline 26 & MEL & 80 & $\sqrt{ }$ & \\
\hline 27 & IGR & 70 & $\sqrt{ }$ & \\
\hline 28 & $\mathrm{KD}$ & 100 & $\sqrt{ }$ & \\
\hline 29 & LEB & 50 & & $\sqrt{ }$ \\
\hline 30 & NKI & 90 & $\sqrt{ }$ & \\
\hline & Jumlah & 30 & 25 & 5 \\
\hline & lai Rata-Rata & 80,66 & & \\
\hline \multicolumn{3}{|c|}{ Presentasi } & $\mathbf{8 3 , 3 3 \%}$ & $16,67 \%$ \\
\hline
\end{tabular}

Berdasarkan tabel diatas, terlihat bahwa yang telah mencapai KKM adalah 25 orang sekitar 83,33\% . Hasil tes pembelajaran IPS pada siklus II telah mencapai Kriteria Ketuntasan Minimal (KKM) dengan nilai 100\%. Nilai tes siklus II tersebut telah dikatakan memuaskan karena hasilnya baik dan mencapai dan mencapai target pencapaian penilaian yang tetapkan yaitu $>65 \%$. 


\section{d. Refleksi}

Berdasarkan hasil tes dalam proses pembelajaran secara keseluruhan menunjukkan bahwa siswa menyukai pembelajaran IPS dalam proses pembelajaran secara keseluruhan menunjukkan bahwa siswa menyukai pembelajaran IPS dengan materi peninggalan sejarah melalui model make a match. Pembelajaran dengan menggunakan model make a match menjadikan siswa lebih berperan aktif dalam proses pembelajaran, sehinngga mereka lebih mudah dalam memahami materi pelajaran yang diberikan karena siswa mendemonstrasikannya langsung. Dari hasil tes yang telah dicapai oleh siswaselama proses pembelajaran IPS dengan materi peninggalan sejarah pada siklus II telah berhasil maka tidak perlu lagi dilakukan siklus berikutnya.

\section{PEMBAHASAN}

Pemerolehan hasil penelitian merujuk pada pemerolehan skor yang dicapai siswa ketika tes akhir siklus.Sebelum peneliti melakukan penelitian tindakan kelas pada kelas IV SD Inpres Kobisonta A1, peneliti terlebih dahulu melakukan observasi awal dan wawancara terhadap guru mata pelajaran IPS kelas IV.Hal inidilakukan dengan tujuan untuk mengetahui gambaran kondisi awal siswa tentang pembelajaran IPS, khususnya materi peninggalan sejarah, peneliti kemudian melakukan penelitian tindakan kelas yang dilakukan dalam dua siklus yaitu siklus I dan siklus II. Siklus II dilaksanakan apabila pada siklus I terdapat beberapa kekurangan yang dapat diketahui dari hasil tes pada siklus I. Dari kegiatan tes tersebut kemudian dapat disimpulkan kegiatan apa saja yang harus dilakukan untuk memperbaiki pembelajaran pada siklus selanjutnya. Penelitian menggunakan model make a match untuk meningkatkan hasil belajar siswa pada materi peninggalan sejarah pada siswa kelas IV SD Inpres Kobisonta A1.

Hasil tes akhir siklus I yang dilaksanakan pada pertemuan kedua ini menunjukkan bahwa siswa yang memiliki nilai <65 sebanyak 16 orang atau 53,33\% sedangkan siswa yang memperoleh nilai 265 sebanyak 14 orang atau 46,67\%. Dengan demikian persentasi siswa yang telah mencapai KKM atau memperoleh $\searrow 65$ adalah sebesar 46,67\%. Hal ini menunjukan bahwa pelaksanaan siklus I belum mencapai indicator keberhasilan yaitu lebih dari 65\% siswa memperoleh nilai 65.Rata-rata tes akhir siklus I juga menunjukan belum mencapai standar ketuntasan minimal yaitu 65. Berdasarkan hasil observasi atau pengamatan pada siklus I, guru dan siswa telah melakukan pembelajaran yang sesuai dengan rencana pembelajaran yang telah disiapkan, namun masih terdapat banyak masalah baik yang berhubungan dengan kondisi dan sikap siswa dalam menerima pelajaran belum maksimal, pelajaran masih didominasi oleh siswa yang dianggap lebih pandai. Melihat 
kekurangan yang masih ada serta pelaksanaan tindakan siklus I yang belum memenuhi criteria keberhasilan yang ditetapkan, maka penelitian dilanjutkan pada siklus II.

Dengan memperhatikan kelemahan-kelemahan pada siklus I ini maka pada siklus II dirancang tindakan untuk meningkatkan hasil belajar siswa yaitu pemberian pengharggan untuk memotivasi siswa belajar dan semakin bertanggung jawab selain itu diberikan lembaran kerja siswa (LKS). LKS diperbanyak dengan tujuan untuk

meningkatan keterlibatan siswa dalam proses pembelajaran. Dari keseluruhan siklus yang terdiri dari 4 pertemuan, diperoleh data peningkatan nilai tes persiklus. Hasil yang meningkat ini menunjukkan bahwa guru sudah mampu menerapkan model make a match untuk mengetahui hasil belajar siswa dengan materi peninggalan sejarah pada kelas IV SD Inpres Kobisonta A1 model make a match sudah dapat diterapkan dengan baik oleh guru. Pelaksanaan pembelajaran sesuai dengan RPP yang

disusun.Sementara siswa sudah dapat aktif dalam pembelajaran. Dengan melihat peningkatan terhadap hasil belajar siswadimana pada siklus II ini 83,33\% telah mencapai Standar Ketuntasan Minimal (SKM) yang ditetapkan dan rata-rata kelas yang memenuhi KKM maka pelaksanaan tindakan pada siklus II dinyatakan berhasil dan diputuskan untuk tidak dilanjutkan pada siklus berikutnya. Ini berarti peningkatan hasil belajar siswa dengan materi peninggalan sejara model make a match pada siswa kelas IV SD Inpres Kobisonta A1 dapat ditingkatkan. Adapun grafik pencapaian KKM pada siklus I dan II dapat terlihat pada gambar berikut :

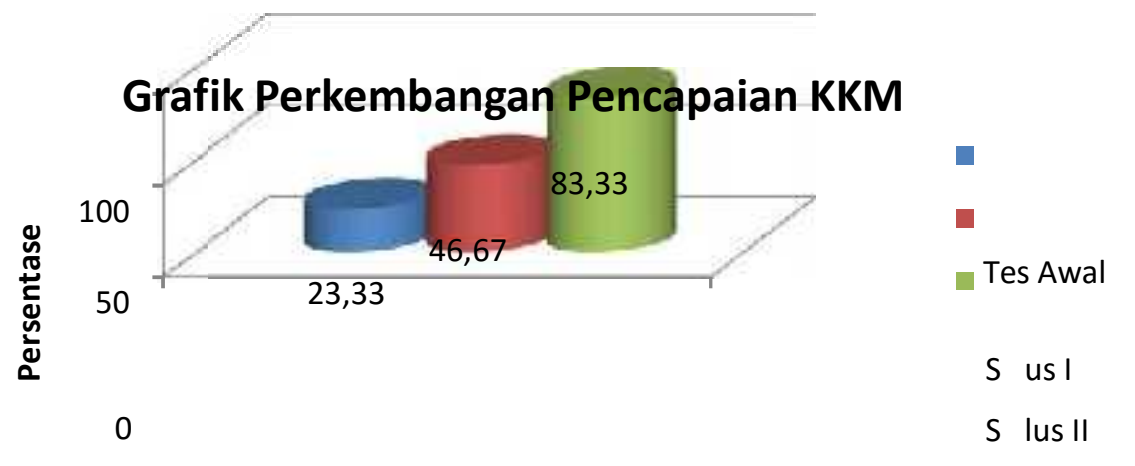

Nilai Siswa

\section{Gambar 1. Peningkatan KKM Tiap Siklus}

Dengan demikian, dapat disimpulkan secara umum model pembelajaran make a match dapat meningkatkan hasil belajar IPS siswa kelas IV SD Inpres Kobisonta A1 pada materi peninggalan sejarah. Selain itu,hal ini juga didukung dengan 
meningkatnya minat dan keaktifan siswa dalam pembelajaran yang tampak meningkat pada observasi dan hasil refleksi dari setiap siklus.

\section{KESIMPULAN}

Hasil belajar IPS dengan materi peninggalan sejarah pada siswa kelas IV SD Inpres Kobisonta A1 setelah mengikti pembelajaran dengan model make a match mengalami peningkatan dari siklus I dan siklus II. Nilai rata-rata pada siklus I adalah $58,66 \%$ atau termasuk kategori kurang, sedangkan nilai rata-rata pada siklus ke II sebesar $80,66 \%$ atau termasuk kategori baik. Peningkatan tersebut menunjukkan pembelajaran IPS dengan materi peninggalan sejarah model make a match pada kelas IV SD Inpres Kobisonta A1 dapat berhasil dengan baik.

\section{DAFTAR PUSTAKA}

Benyamin S. Bloom, 1976, Taksonomi Of Educational Objectives : New York. David Mackay.

Daldjoeni. 1981. Dasar-dasar Ilmu Pengetahuan Sosial. Bandung : Alumni.

Hisyam Zaini. 2008. Strategi Pembelajaran Aktif. Yogyakarta: Pustaka Insan Madani.

Kapata Arkeologi. 2009 Jurnal Arkeologi Wilayah Maluku dan Maluku Utara.

Muhamad. A. 2005. Penelitian Kependidikan.Bandung, Aksara.

Nana Sudjana. 1989. Penelitian dan Penelitian Pendidikan, Bandung: Sinar Baru.

Pakem. 2006.Pembelajaran Aktif Kreatif Efektif Menyenangkan, IPS KTSP. Teguh Karya.

Ratumanan, T. G. 2002. Belajar dan Pembelajaran. Surabaya. Unessa University Press

Slameto. 2003. Belajar dan Faktor-Faktor yang Mempengaruhinya. Jakarta: Rineka cipta.

Sumadi Suryabrata. 1983. Psikologi Pendidikan. Jakarta : PT Raja Grafindo Persada Jakarta.

Suryabrata. 2004. Penelitian Pendekatan, Teori, Metode, Teknih dan Kiat. Yogyakarta: Unit Penerbitan Sastra Asia Barat Fakultas Ilmu Budaya Universitas Gajah Mada.

Tim Bina Karya Guru. 2006 IPS TERPADU. KTSP, Erlangga.

Winkel, 1991. Psikologi Pengajaran, Jakarta.PT.Grasindo. 